\title{
Factors associated with speed of diagnosis, referral, and treatment in colorectal cancer
}

\author{
CHRISTINE MACARTHUR' AND ALWYN SMITH ${ }^{2}$ \\ From the Department of Social Medicine ${ }^{1}$ University of Birmingham, Birmingham B15 2TJ, and Department \\ of Epidemiology and Social Research, ${ }^{2}$ University Hospital of South Manchester, Manchester M20 9QL, UK
}

SUMMARY Delay in the presentation of symptoms and in referral of patients for surgical opinion remains an important problem in colorectal cancer. Factors influencing patients to consult early include advice from close family or other associates and abdominal pain or vomiting, or both, as one of the early symptoms. More localised rectal symptoms and loss of weight are often associated with long delay. The "classic" symptom pictures are not often seen in the early stages of the disease. Few identifiable factors were associated with delay in referral for surgical opinion. Doctors who examine their patients (rectally or otherwise) refer them sooner. In the districts studied delay in instituting definitive treatment after consultant referral does not seem to be a major problem. There is some evidence that delay is associated with stage of the disease at presentation.

The large bowel is one of the more common sites for malignant tumours and more than 20000 cases of colorectal cancer are registered annually in the United Kingdom. Mortality remains relatively unchanged, and there is no evidence that advances in treatment have materially improved survival. Many writers have considered whether earlier diagnosis could be achieved and whether it might improve survival..$^{1-5}$ It is always difficult to show that earlier diagnosis improves survival but there are good grounds for believing that easier resectability leads to an improved quality of residual life, and few students of this disease doubt that it would be beneficial to achieve diagnosis and treatment at an earlier stage than is usual at present.

We report a study of factors associated with delay in presentation, diagnosis, and referral for treatment.

\section{Method}

The study population comprised all patients diagnosed as having cancer of the colon and rectum during a 12 month period in two health districts in the North-West Region. The study distinguished three phases in the pretreatment history: from the patient's first awareness of a symptom to first medical consultation (phase I); from first consultation to referral for specialist opinion (phase II), and from referral to the hospital specialist to definitive treatment (phase III). These phases correspond broadly to what other authors have called patient delay, general practitioner delay, and hospital delay-terms that we prefer to avoid since they seem to carry imputations of responsibility that cannot always be justified.

The main source of information for the study was a detailed interview with each patient soon after the institution of definitive treatment (carried out by $\mathrm{CM})$. Further information and corroboration were obtained from general practitioners and abstracts from case notes. In many cases dates were available for the various important events. In other cases, especially if the history was a long one, we recorded the midpoint of the period recalled, either the month or part of a year.

During the year 187 cases of large bowel cancer were diagnosed and 127 patients (68\%) were interviewed. No patient refused to take part. Reasons for not interviewing were that the patient had died (in several cases before the malignancy was discovered), or was too ill or confused, or could not be contacted. Information was available from case notes for these patients and it was therefore possible to consider in what ways their exclusion from the main part of the study might bias our results. In the non-interviewed group of patients there was slightly more delay in phase I and much less delay in phase III, which is not surprising since this group included most of the patients who had been admitted as emergencies and had died shortly after treatment. 
Results

\section{SYMPTOMS}

Most patients in this study experienced several symptoms during the early course of the disease. The symptoms experienced at various points in the sequence up to treatment were noted separately (table 1). The average number of initial symptoms experienced was 2.5 ; it was 3 by the time of first medical consultation and 3.5 at the time of referral. Only one patient developed further symptoms after referral. Abdominal pain was the most frequently reported symptom at all stages and by the time of referral over half the sample $(81.5 \%$ of patients with cancer of the colon) had experienced this. Diarrhoea was the next most frequently reported symptom followed by rectal bleeding, this latter being experienced by $68 \%$ of the patients with rectal cancer.

Table 1 Cumulative percentage of patients reporting symptoms at various stages

\begin{tabular}{|c|c|c|c|c|c|}
\hline \multirow[b]{2}{*}{ Symptom } & \multirow[b]{2}{*}{ Initial } & \multirow{2}{*}{$\begin{array}{l}\text { By first } \\
\text { consultation }\end{array}$} & \multicolumn{3}{|c|}{ By referral } \\
\hline & & & All & Colon* & Rectum \\
\hline Abdominal pain & 48 & 52 & 57 & $81 \cdot 5$ & 22 \\
\hline Diarrhoea & 38.5 & 40 & 45 & & \\
\hline Constipation & 21 & 23 & 25 & & \\
\hline $\begin{array}{l}\text { Alternate diarrhoea/ } \\
\text { constipation }\end{array}$ & $5 \cdot 5$ & 7 & 11 & & \\
\hline Rectal bleeding & 32 & $38 \cdot 5$ & 46 & 31 & 68 \\
\hline Rectal pain & 14 & $16 \cdot 5$ & 18 & 9 & 30 \\
\hline Mucus & $12 \cdot 5$ & 15 & 17 & 9 & 28 \\
\hline Nausea/vomiting & $16 \cdot 5$ & 20 & $24 \cdot 5$ & $38 \cdot 5$ & 4 \\
\hline Weight loss & 23 & 27 & 37 & & \\
\hline Appetite loss & $16 \cdot 5$ & 20 & 25 & & \\
\hline Lassitude & 14 & 18 & 21 & & \\
\hline Abdominal swelling & 2 & 4 & $5 \cdot 5$ & & \\
\hline Other & 13 & 16 & 21 & & \\
\hline
\end{tabular}

*Figures are given separately for colon and rectum where there is a statistically significant difference between the symptom of the two sites.

\section{PHASE I DELAY}

Few patients in this study went to the doctor within a week of first noticing their symptoms, although $45 \%$ had consulted within a month. This lack of immediate action is not surprising since many of the early symptoms of cancer of the large bowel are those associated with transient non-serious disease. But some patients delayed much longer, $28 \%$ delaying more than three months before consulting a doctor. Mean phase I delay was 94.5 days and median delay $31 \cdot 5$ days. Table 2 shows the detailed distribution.

Personal characteristics such as age and social class are often reported to be associated with use of medical services, and in relation to some cancers, such as breast, they are associated with patient delay. We found no such associations for colorectal cancer.
Two important sets of factors were associated with promptness of consultation with the doctor-advice the patient received from immediate family and associates and the nature of the symptoms. Personal advice to go to the doctor was important in reducing delay (table 3 ). It made little difference whether the advice was from spouse, parent, child, or friend. Patients with abdominal pain (table 4 ) or nausea and vomiting (table 5) as an initial symptom went more quickly to the doctor; those with both these symptoms going most quickly. Probably the degree of discomfort produced by these symptoms prompts consultation.

Table 2 Duration of phase I delay showing colon and rectum cases separately

\begin{tabular}{|c|c|c|c|c|c|c|}
\hline \multirow{2}{*}{$\begin{array}{l}\text { Consulted } \\
\text { within }\end{array}$} & \multicolumn{2}{|l|}{$A l l$} & \multicolumn{2}{|c|}{ Colon } & \multicolumn{2}{|c|}{ Rectum } \\
\hline & No & Cum \% & No & Cum \% & No & Cum \% \\
\hline $\begin{array}{l}1 \text { week } \\
1 \text { month } \\
3 \text { months } \\
6 \text { months } \\
1 \text { year } \\
>1 \text { year } \\
\text { No information }\end{array}$ & $\begin{array}{r}19 \\
33 \\
31 \\
14 \\
13 \\
6 \\
11\end{array}$ & $\begin{array}{c}16 \cdot 5 \\
45 \\
72 \\
84 \\
95 \\
100\end{array}$ & $\begin{array}{r}11 \\
22 \\
21 \\
7 \\
4 \\
3\end{array}$ & $\begin{array}{l}16 \\
48 \cdot 5 \\
79 \cdot 5 \\
90 \\
95 \cdot 5 \\
100\end{array}$ & $\begin{array}{r}8 \\
11 \\
10 \\
7 \\
9 \\
3\end{array}$ & $\begin{array}{l}16 \\
39 \cdot 5 \\
60 \cdot 5 \\
75 \\
94 \\
100\end{array}$ \\
\hline
\end{tabular}

Cum $\%=$ Cumulative percentage.

Table 3 Association between phase I delay and discussion of symptoms in social network

\begin{tabular}{lll}
\hline $\begin{array}{l}\text { Consulted } \\
\text { within }\end{array}$ & $\begin{array}{l}\text { Discussed } \\
\text { symptoms } \\
(n=54)\end{array}$ & $\begin{array}{l}\text { Did not discuss } \\
\text { symptoms } \\
(n=49)\end{array}$ \\
\hline & Cum \% & $\begin{array}{c}\text { Cum } \% \\
1 \text { week }\end{array}$ \\
1 month & 19 & 5 \\
3 months & 48 & 16 \\
6 months & 74 & 52.5 \\
Median delay & 84 & 74
\end{tabular}

Kruskal-Wallis test $p=<0.05$.

(No information $=24$ ).

Cum $\%=$ Cumulative percentage.

Table 4 Association between phase I delay and abdominal pain

\begin{tabular}{lll}
\hline $\begin{array}{l}\text { Consulted } \\
\text { within }\end{array}$ & $\begin{array}{l}\text { As initial } \\
\text { symptom } \\
(n=54)\end{array}$ & $\begin{array}{l}\text { Not as initial } \\
\text { symptom } \\
(n=49)\end{array}$ \\
\hline & Cum \% & $\begin{array}{l}\text { Cum } \% \\
\text { week }\end{array}$ \\
1 month & 22 & 12 \\
3 months & $55 \cdot 5$ & 35 \\
6 months & 78 & 59 \\
Median delay & 91 & 71.9 \\
\hline
\end{tabular}

Kruskal-Wallis test $\mathbf{p}=<0.01$.

(No information $=24$ ).

Cum $\%=$ Cumulative percentage. 
Symptoms associated with long delay were loss of weight and rectal discomfort or pain. Weight fluctuation is not uncommonly experienced by healthy people. It is often a gradual process resulting in considerable lapse before the person feels able justifiably to consult a doctor. Long delay for patients with rectal discomfort could be explained by the association between this symptom and haemorrhoids, a disease which many consider as not requiring medical attention. Patients with cancer of the colon were more likely to experience the symptoms of abdominal pain and vomiting, and this explains why they delay less than patients with rectal cancer.

\section{PHASE II DELAY}

For some cancers phase II delay is uncommon, and we found little delay for breast cancer in the same districts. ${ }^{6}$ But there was considerable phase II delay for some of the colorectal patients in this study. Only $32 \%$ were referred to a specialist immediately, this proportion rising to just over half by the time a month had elapsed. Thirty per cent of the patients were delayed for longer than three months. Mean delay was 120.5 days and median delay 25.25 days (table 6). Again there was a little more delay in patients with cancer of the rectum than colon, this small difference being due mainly to a larger number of particularly long delays occurring in several rectum cases. The nature of the symptoms the patient presented to the doctor did not seem to play a large part in affecting this phase of delay, although patients with constipation were referred a little more quickly (table 7) and patients with diarrhoea and those with only one symptom more slowly. Patients from the manual social classes also waited a little longer than middle class patients (table 8). Whether the patient was examined by the doctor at the first consultation was found to be associated with speed of referral. Median delay for patients who had been examined was $1 \cdot 5$ (both rectal and abdominal examination) and 2.5 days (either type of examination) compared with 89.5 days in the 42 cases where no physical examination took place (table 9). A longer duration of symptoms does not seem to prompt the doctor into more immediate action; there was no association between long phase I delay and either being examined at the first visit or being referred more quickly.

\section{PHASE III DELAY}

Once the patients had been referred to a consultant over half $(58 \%)$ had been treated within a month of the date of the doctor's referral letter (table 10). This delay phase comprised two parts: waiting to see a specialist (usually at an outpatient clinic) and waiting,
Table 5 Association between phase I delay and nausea/vomiting

\begin{tabular}{lll}
\hline $\begin{array}{l}\text { Consulted } \\
\text { within }\end{array}$ & $\begin{array}{l}\text { As initial } \\
\text { symptom } \\
(n=19)\end{array}$ & $\begin{array}{l}\text { Not as initial } \\
\text { symptom } \\
(n=87)\end{array}$ \\
\hline week & Cum \% & $\begin{array}{l}\text { Cum } \% \\
1 \text { month }\end{array}$ \\
3 months & 26 & 16 \\
6 months & 74 & 40 \\
Median delay & 89.5 & 68 \\
\hline
\end{tabular}

Kruskal-Wallis test $\mathbf{p}=<0.02$.

(No information $=21$ ).

Cum $\%=$ Cumulative percentage.

Table 6 Duration of phase II delay also showing colon and rectum cases separately

\begin{tabular}{|c|c|c|c|c|c|c|}
\hline \multirow{2}{*}{$\begin{array}{l}\text { Consulted } \\
\text { within }\end{array}$} & \multicolumn{2}{|c|}{ Colon } & \multicolumn{2}{|c|}{ Rectum } & \multicolumn{2}{|l|}{$A l l$} \\
\hline & No & . Cum \% & No & Cum \% & No & Cum \% \\
\hline 2 days & 20 & 31 & 16 & 35 & 36 & 32 \\
\hline 2 weeks & 9 & 45 & 3 & 40 & 12 & $42 \cdot 5$ \\
\hline 1 month & 7 & 56 & 4 & 50 & 11 & $52 \cdot 5$ \\
\hline 3 months & 13 & 76 & 7 & $62 \cdot 5$ & 20 & 70 \\
\hline 6 months & 8 & 88 & 5 & 73 & 13 & $81 \cdot 5$ \\
\hline Over 6 months & 8 & 100 & 13 & 100 & 21 & 100 \\
\hline No information & 10 & & 4 & & 14 & \\
\hline
\end{tabular}

Cum $\%=$ Cumulative percentage.

Table 7 Association between phase II delay and constipation as a sympton at first consultation

\begin{tabular}{lll}
\hline Referred within & $\begin{array}{l}\text { Constipation } \\
(n=25)\end{array}$ & $\begin{array}{l}\text { No constipation } \\
(n=85)\end{array}$ \\
\hline & Cum \% & Cum \% \\
2 days & 48 & 28 \\
3 meeks & 60 & 39 \\
Median delay & 88 & 66 \\
\hline
\end{tabular}

Kruskal-Wallis test $\mathbf{p}=<0.02$.

(No information $=17$ ).

Cum $\%=$ Cumulative percentage.

Table 8 Association between phase II delay and social class

\begin{tabular}{lll}
\hline & $\begin{array}{l}\text { Social classes } \\
I, I I, \text { and IINM } \\
(n=36)\end{array}$ & $\begin{array}{l}\text { Social classes } \\
\text { IIIM, } I V \text {, and } V \\
(n=72)\end{array}$ \\
\hline Referred within & Cum \% & Cum \% \\
2 days & 47 & 24 \\
2 weeks & 56 & 36 \\
months & 81 & 65 \\
Median delay & 5.5 days & 39.5 days \\
\hline
\end{tabular}

Kruskal-Wallis test $\mathrm{p}=<0.05$.

(No information $=19$ ).

Cum $\%=$ Cumulative percentage. 
after specialist consultation, to be admitted and treated. Treatment generally took longer than admittance, median delays being five days and 15 days. Overall median delay was 24 days, which was mainly due to first waiting for the appropriate clinic day to see a specialist, then waiting until a bed was available-in other words a combination of health resources and administrative procedures.

Over two thirds of the patients were investigated after their first specialist consultation and before definitive treatment. Thirty one per cent of the patients had a barium enema/x ray, $27 \%$ an endoscopy, and $9.5 \%$ both. In the hospitals in this study the waiting lists for these investigations were relatively short. Table 11 shows that the median delay for patients who had an investigation was not significantly greater than for patients who had no investigations. The only exception was the 12 patients who had both types of investigation who were delayed a little longer.

In general, type of symptoms was not associated with phase III delay. The only exception was that patients with rectal bleeding were more likely to experience phase III delay, only $44.5 \%$ having been treated within a month compared with $70.5 \%$ of those without this symptom. Possibly some had been referred with a tentative diagnosis of haemorrhoids and were therefore not given an urgent appointment. In the few cases where there was considerable hospital delay, this was mainly a result of their being treated for another disease since some patients had additional abdominal conditions that initially masked the cancer.

\section{OVERALL DELAY AND SPREAD OF TUMOUR}

Median overall delay from the onset of first symptoms to definitive treatment was 189.5 days, just over six months (table 12).

Other studies have examined overall delay in bowel cancer and stage of tumour at treatment, with conflicting results. We were not primarily concerned with this issue but our findings are presented here briefly. From data recorded in the Regional Cancer Registry the degree of spread of the tumour was categorised into localised, direct spread, regional lymph node involvement, direct spread together with regional lymph node involvement, and distant metastases. This is more general than the usual Duke's classification, which was not available to us. Table 13 shows that there was a significant positive association between overall delay and degree of spread of the tumour.

\section{Discussion}

Delay, in particular on the part of the patient and the general practitioner, is still a considerable problem in
Table 9 Association between being given a rectal or abdominal examination, or both, at their first medical consultation, and phase II delay

\begin{tabular}{llll}
\hline Referred within & $\begin{array}{l}\text { Both exams } \\
(n=22)\end{array}$ & $\begin{array}{l}\text { Just one exam } \\
(n=36)\end{array}$ & $\begin{array}{l}\text { No exam } \\
(n=42)\end{array}$ \\
\hline & Cum $\%$ & Cum $\%$ & Cum $\%$ \\
2 days & 50 & 50 & 9.5 \\
2 weeks & 59 & 67 & 19 \\
1 month & 73 & 72 & 31 \\
3 months & 91 & 83 & 52 \\
Median delay & 1.5 days & 2.5 days & 89.5 days \\
\hline
\end{tabular}

Kruskal-Wallis test $p=<0.001$.

(No information $=27$ ).

Cum $\%=$ Cumulative percentage.

Table 10 Duration of phase III delay, also showing colon and rectum cases separately

\begin{tabular}{|c|c|c|c|c|c|c|}
\hline \multirow{2}{*}{$\begin{array}{l}\text { Treated } \\
\text { within }\end{array}$} & \multicolumn{2}{|l|}{$A l l$} & \multicolumn{2}{|c|}{ Colon } & \multicolumn{2}{|c|}{ Rectum } \\
\hline & No & Cum \% & No & Cum \% & No & Cum \% \\
\hline $\begin{array}{l}2 \text { days } \\
1 \text { week } \\
2 \text { weeks } \\
1 \text { month } \\
6 \text { weeks } \\
3 \text { months } \\
6 \text { months } \\
>6 \text { months } \\
\text { No information }\end{array}$ & $\begin{array}{r}9 \\
10 \\
16 \\
32 \\
15 \\
20 \\
6 \\
7 \\
14\end{array}$ & $\begin{array}{c}8 \\
16 \cdot 5 \\
30 \cdot 5 \\
58 \\
71 \\
89 \\
94 \\
100\end{array}$ & $\begin{array}{r}9 \\
7 \\
8 \\
15 \\
6 \\
12 \\
6 \\
5\end{array}$ & $\begin{array}{l}13 \\
23 \cdot 5 \\
35 \\
57 \cdot 5 \\
66 \\
84 \\
92 \cdot 5 \\
100\end{array}$ & $\begin{array}{r}- \\
3 \\
8 \\
17 \\
9 \\
8 \\
-\end{array}$ & $\begin{array}{r}-6 \\
23 \\
60 \\
79 \\
96 \\
96 \\
100\end{array}$ \\
\hline
\end{tabular}

Cum $\%=$ Cumulative percentage.

Table 11 Association between delay from specialist consultation to treatment and investigations

\begin{tabular}{|c|c|c|c|c|}
\hline $\begin{array}{l}\text { Treated } \\
\text { within }\end{array}$ & $\begin{array}{l}\text { Had barium } \\
\text { enema } \\
(n=38)\end{array}$ & $\begin{array}{l}\text { Had } \\
\text { endoscopy } \\
(n=32)\end{array}$ & $\begin{array}{l}\text { Had } \\
\text { both } \\
(n=12)\end{array}$ & $\begin{array}{l}\text { Had } \\
\text { neither } \\
(n=38)\end{array}$ \\
\hline $\begin{array}{l}2 \text { weeks } \\
1 \text { month } \\
2 \text { months }\end{array}$ & $\begin{array}{l}\text { Cum \% } \\
45 \\
74 \\
87\end{array}$ & $\begin{array}{l}\text { Cum \% } \\
28 \\
84 \\
84\end{array}$ & $\begin{array}{l}\text { Cum \% } \\
27 \\
45 \\
91\end{array}$ & $\begin{array}{l}\text { Cum \% } \\
63 \\
82 \\
84\end{array}$ \\
\hline Median delay & 16 days & 18 days & 35 days & 12 days \\
\hline
\end{tabular}

Cum $\%$ = Cumulative percentage.

Table 12 Duration of overall delay showing colon and rectum cases separately

\begin{tabular}{|c|c|c|c|c|c|c|}
\hline \multirow{2}{*}{$\begin{array}{l}\text { Treated } \\
\text { within }\end{array}$} & \multicolumn{2}{|l|}{$A \boldsymbol{l l}$} & \multicolumn{2}{|c|}{ Colon } & \multicolumn{2}{|c|}{ Rectum } \\
\hline & No & Cum \% & No & Cum \% & No & Cum \% \\
\hline $\begin{array}{l}1 \text { week } \\
1 \text { month } \\
2 \text { months } \\
3 \text { months } \\
6 \text { months } \\
1 \text { year } \\
2 \text { years } \\
>2 \text { years } \\
\text { No information }\end{array}$ & $\begin{array}{r}3 \\
7 \\
11 \\
11 \\
24 \\
36 \\
19 \\
7 \\
9\end{array}$ & $\begin{array}{c}2 \cdot 5 \\
8 \cdot 5 \\
18 \\
27 \cdot 5 \\
47 \cdot 5 \\
78 \\
94 \\
100\end{array}$ & $\begin{array}{r}3 \\
7 \\
6 \\
9 \\
12 \\
22 \\
9 \\
3\end{array}$ & $\begin{array}{l}4 \\
14 \\
22 \cdot 5 \\
35 \\
52 \\
83 \\
96 \\
100\end{array}$ & $\begin{array}{r}- \\
5 \\
2 \\
12 \\
14 \\
10 \\
4\end{array}$ & $\begin{array}{r}- \\
-11 \\
15 \\
40 \\
70 \\
91 \\
100\end{array}$ \\
\hline
\end{tabular}

Cum $\%=$ Cumulative percentage. 
Table 13 Association between overall delay and spread of the tumour

\begin{tabular}{|c|c|c|c|c|}
\hline $\begin{array}{l}\text { Treated } \\
\text { within }\end{array}$ & $\begin{array}{l}\text { Localised } \\
(n=12)\end{array}$ & $\begin{array}{l}\text { Direct } \\
\text { spread } \\
(n=59)\end{array}$ & $\begin{array}{l}\text { Some } \\
\text { regional } \\
\text { lymph } \\
\text { involvement } \\
(n=25)\end{array}$ & $\begin{array}{l}\text { Distant } \\
\text { metastases } \\
(n=18)\end{array}$ \\
\hline $\begin{array}{l}2 \text { months } \\
3 \text { months } \\
6 \text { months } \\
1 \text { year }\end{array}$ & $\begin{array}{l}\text { Cum \% } \\
33 \\
67 \\
67 \\
83\end{array}$ & $\begin{array}{l}\text { Cum \% } \\
22 \\
29 \\
52 \cdot 5 \\
78\end{array}$ & $\begin{array}{l}\text { Cum \% } \\
12 \\
16 \\
32 \\
68\end{array}$ & $\begin{array}{l}\text { Cum \% } \\
5 \cdot 5 \\
17 \\
39 \\
72\end{array}$ \\
\hline Median delay & 76.5 days & 156 days & 248 days & 226.5 days \\
\hline
\end{tabular}

Kruskal-Wallis test $\mathrm{p}<0.05$.

(No information $=13$ ).

Cum $\%=$ Cumulative percentage.

* Since only four patients were categorised as having only regional lymph node involvement and 21 as having direct spread plus regional node involvement we have grouped these together. Median delay for these four (237.5 days) is not significantly different.

cancer of the large bowel. Unlike breast cancer this malignancy has enjoyed little publicity in the media. Most patients $(90 \cdot 5 \%)$ reported that they had not considered cancer as a possible cause of their symptoms (compared with $50 \%$ in patients with breast cancer) and had delayed consulting their doctor until such symptoms became either more severe or more persistent. The only patients who went quickly were those whose symptoms produced considerable initial discomfort. In common with others-for instance, Keddie and Hargreaves ${ }^{7}$-we found that there is no outstanding typical symptom picture. The symptoms are rather non-specific and difficult to differentiate from those of transient or non-serious disease. Although it seems reasonable to argue that if they persist and remain unexplained they should be reported to a doctor, it would be quite difficult to design a health education programme to explain this without the risk of causing unnecessary anxiety and excessive recourse to medical consultation. We are presently considering the design of such a programme for trial and evaluation.

Any such programme would have to be accompanied by arrangements to ensure that medical attention is instituted quickly. This did not occur for many patients in this study. On average, the patients were delayed by their doctors as long as they delayed themselves. This is clearly also an issue that requires further attention. One important finding was the association between delay and failure on the part of the doctor to carry out a physical examination, either rectal or abdominal. Others have also noted that several of the patients in their studies were delayed as a result of failure to examine. ${ }^{14}$ Nevertheless, this association may not be causal. It may simply indicate that delay in referral is less likely among doctors whose habit it is to examine rather than that examination leads to discovery of a lesion needing $\frac{T}{\mathbb{D}}$ specialist investigation. ${ }^{8}$

Perhaps the major cause of general practitioner delay is the large number of patients presenting with $\overrightarrow{\vec{F}}$ symptoms similar to those of colorectal cancer. It is difficult to distinguish those with serious bowel disease and clearly impossible to refer all such patients for special investigations. As MacAdam notes, "if it could be shown that one or two symptoms $\varrho$ presenting together to the general practitioner in क certain age/sex groups were associated with a high $\overrightarrow{0}$ probability of serious disease, then delay in diagnosis. might be reduced." $\mathrm{We}$ are in the process of $\vec{\omega}$ examining this hypothesis. A pilot study carried out in association with 10 general practítioners has shown that fewer patients present with these $\vec{\omega}$ symptoms than we expected: about 1.5 per doctor $z$ week. Those with more serious gastrointestina ? disease generally presented with symptoms of long零 $\vec{N}$ duration. It may seem obvious that patients with 0 symptoms of longer duration are more likely to neegु referral, but this did not occur in our sample of $c$ patients with large bowel cancer.

\section{References}

${ }^{1}$ Rowe-Jones DC, Aylett SO. Delay in treatment in carcinoma of colon and rectum. Lancet 1965; ii: 973-6.

${ }^{2}$ Leffall LD. Early diagnosis of colorectal cancer. $C A 1974$; 24: 152-9.

${ }^{3}$ Heald RJ. Causes of delay in the diagnosis of cancer of the rectum and colon. The Practitioner 1977; 219: 339-42.

${ }^{4}$ Holliday HW, Hardcastle JD. Delay in diagnosis and treatment of symptomatic colorectal cancer. Lancet 1979; i: 309-11.

${ }^{5}$ MacAdam DB. A study in general practice of the symptoms and delay patterns in the diagnosis of ? gastrointestinal cancer. J $R$ Coll Gen Pract 1979; 29: $\dot{\sigma}$ 723-9.

- MacArthur C, Smith A. Delay in breast cancer and the nature of presenting symptoms. Lancet 1981; i: 601-3.

${ }^{7}$ Keddie N, Hargreaves A. Symptoms of carcinoma of the colon and rectum. Lancet 1968; ii: 749-50.

${ }^{8}$ MacArthur C, Smith A. Delay in the diagnosis of colorectal cancer.J R Coll Gen Pract 1983; 33: 159-61. 